\title{
Analisis tegangan pada batang utama mekanisme bukaan payung raksasa
}

\section{G. Santoso*, M. S. Permana}

Teknik Mesin Fakultas Teknik Universitas Pasunda, Jln. Dr. Setiabudi No. 193 Bandung Jawa Barat Kode Pos : 40154, Telp. (022) 2019435 Fax (022) 2019329.

*Email: gatot.santoso@unpas.ac.id

\section{ARTICLE INFO}

Article History:

Received February 2017

Accepted October 2017

Available online 30 December 2017

\author{
Keywords: \\ Stress analysis \\ Lightweight structure \\ Mechanism \\ Giant umbrella \\ Modelling
}

In cooperation with SNMI XI 2017 Special Edition

\begin{abstract}
Spacious areas as venues for events such as weddings, gatherings, musical performances, bazaars even as parking lots, need to be protected from climate change. Therefore, it is necessary to develop the design of a giant umbrella axle mechanism measuring $12 \times 12$ meters with a height of 8 meters. This paper describes and stresses the stress analysis on the main bar of the giant umbrella opening mechanism. The result of modeling on the stem is presented in the form of stress contour, factor of safety (FOS), and displacement. The largest working voltage is $2 \mathrm{MPa}$ in the connection area, but this voltage is still low when compared with ASTM A36 rod material structure or equivalent to SS-41 which has a yield strength of $100 \mathrm{MPa}$. The low voltage von misses are relevant to FOS values that generally reach 100 or more. The largest displacement value is in the center of the stem, which is $0.3 \mathrm{~mm}$. Thus, the modeling results are able to withstand a load of 1 ton.
\end{abstract}

\section{PENDAHULUAN}

Terinspirasi dari Giant High-Tech Umbrella (Al-Masjid al-Nabawi Umbrella) yang terletak di kota Madinah, Saudi Arabia, maka dilakukan penelitian untuk pengembangan desain mekanisme giant-umbrella yang disesuaikan dengan lahan yang tersedia di kampus IV Universitas Pasundan. Adapun desain yang dilakukan adalah pengembangan mekanisme bukaan payung dan geometri, dimensi serta material struktur giant-umbrella didesain untuk memenuhi kriteria lightweight structure (SL Rasch Engineering, 2013). Kriteria tersebut dilakukan dengan mempertimbangkan dead load and wind load, stress analysis, selection of proper materials, manufacturing planning, dan cost estimation. Selanjutnya akan dilakukan prototyping giant-umbrella untuk menguji fungsi mekanisme dan ketahanan struktur. Tahap awal yang dilakukan adalah melakukan conceptual design yang telah melahirkan berbagai alternatif desain mekanisme dan penggerak mekanisme, selanjutnya dilakukan analisis tegangan untuk setiap komponen yang berperan pada struktur mekanisme bukaan payung raksasa. 
Pada makalah sebelumnya Conceptual design mekanisme payung penutup lahan parkir kendaraan (Santoso, 2016) telah dibahas rangkaian proses desain yang telah dilakukan berdasarkan engineering design loop (Harsokoesomo, 2004) yang biasa dipergunakan untuk merancang sebuah produk dan diterapkan pada perancangan awal payung atau kanopi yang diharapkan dapat menutup lahan berukuran $24 \times 12$ meter sehingga terhindar dari terik matahari di siang hari. Pembahasan kali ini akan difokuskan untuk analisis tegangan pada batang utama payung raksasa desain mekanisme dan struktur penyangga payung.

Analisis tegangan dilakukan pada komponen batang utama 3, 8 dan 9 untuk berbagai posisi dari kondisi tertutup sampai terbuka penuh, bantuan perangkat lunak dioptimalkan sehingga analisis dapat dilakukan dengan cepat serta simulasi gerak dapat ditampilkan.

\section{METODE PENELITIAN}

Optimasi dimensi pada batang utama payung raksasa membutuhkan perhitungan tegangan yang dilakukan untuk setiap posisi mekanisme bukaan payung. Batang utama dipilih untuk dianalisis tegangannya karena semua beban akan dirasakan oleh batang utama tersebut. Metodologi yang dipilih adalah perhitungan numerik dengan memakai perangkat lunak SimWise 4D yang memiliki kemampuan untuk mensimulasikan gerak dan menghitung tegangan serta perpindahan dengan FEA (Sandor, 2005).

SimWise 4D adalah perangkat lunak yang dapat dipergunakan untuk mensimulasikan mekanisme karena mengintegrasikan simulasi gerak mekanisme dan perhitungan tegangan serta perpindahan dengan dasar metode elemen hingga. Pemodelan dapat dilakukan memakai perangkat lunak CAD lain atau langsung di SIM Wise 4D karena perangkat lunak menyediakan fasilitas transfer dengan standar format yang beraneka seperti IGES, Parasolid, ACIS dll. Kemampuan Sim Wise 4D dalam mensimulasikan gerak mekanisme telah teruji walau popularitasnya masih kalah oleh Solid Work yang banyak dipergunakan peneliti dalam menyelesaikan pekerjaannya.

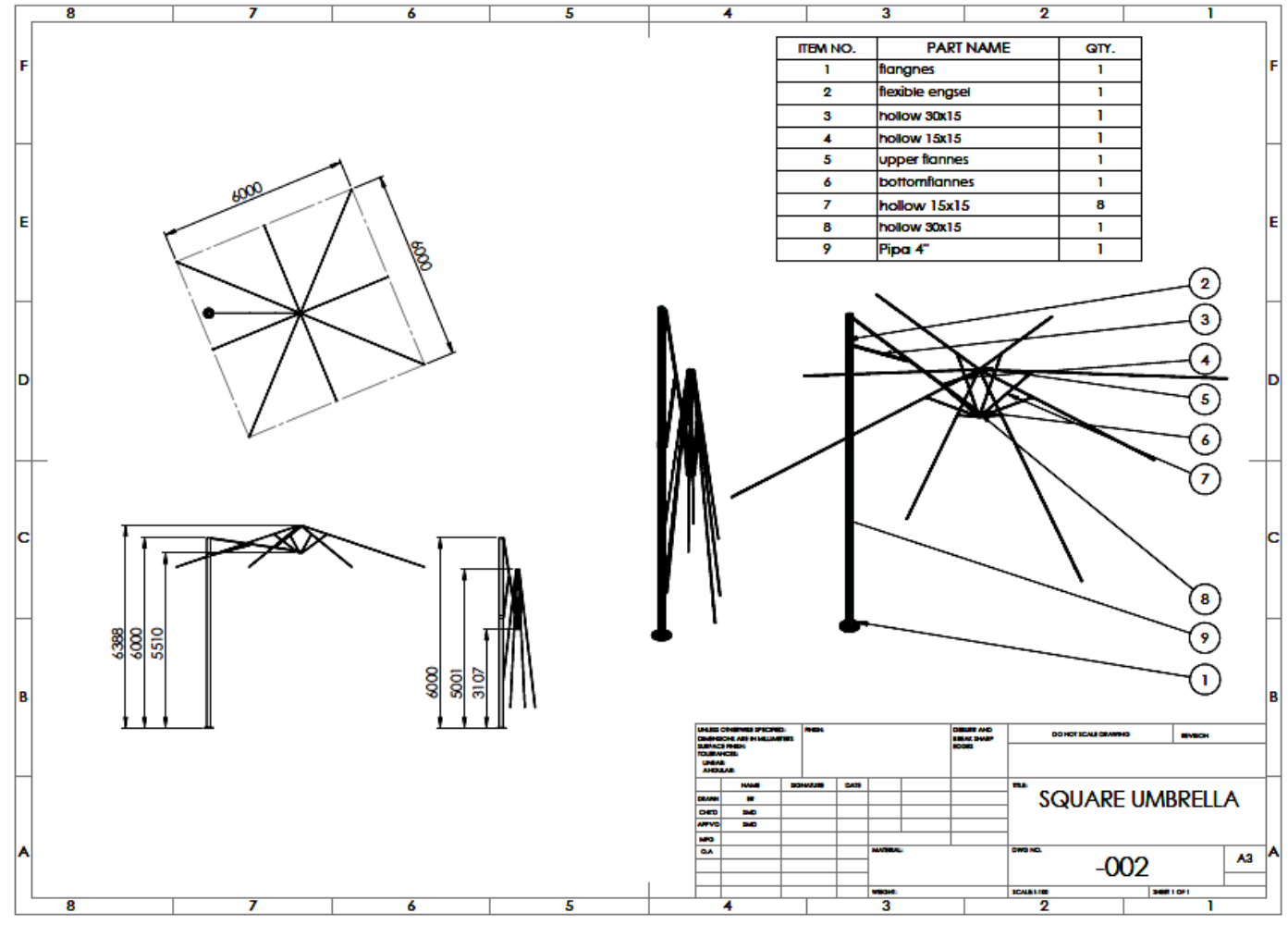

Gambar 1. Desain payung raksasa yang sedang dikembangkan (Santoso, 2016) 


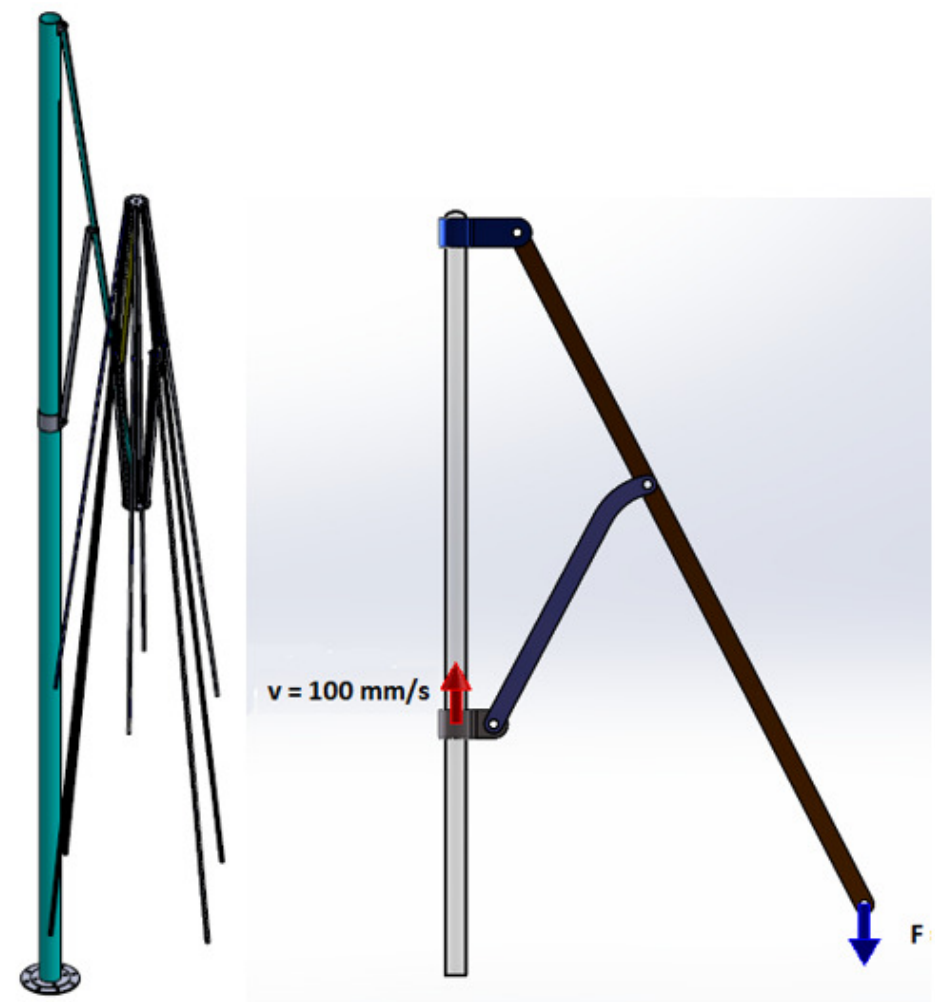

Gambar 2. Diagram benda bebas mekanisme batang utama payung

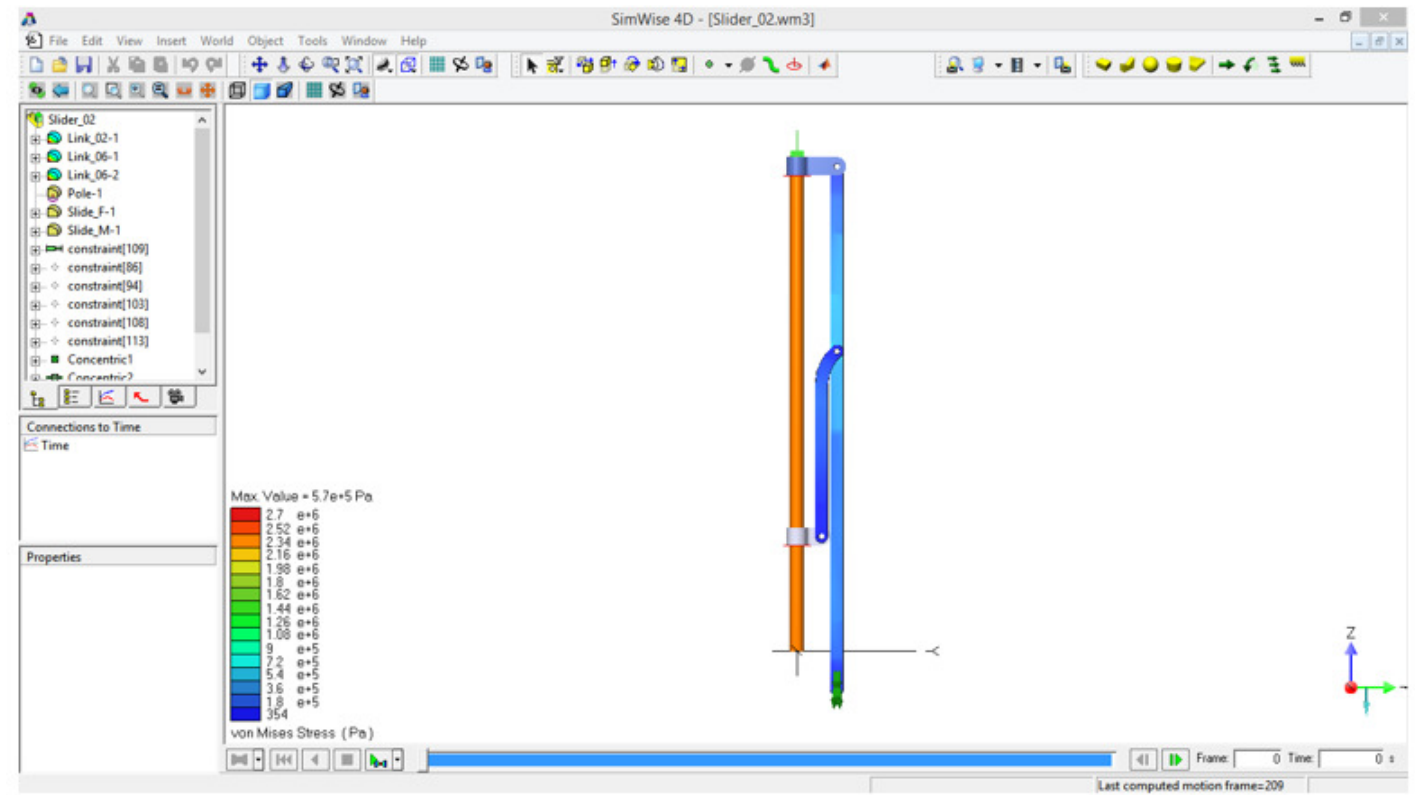

Gambar 3. Model batang utama mekanisme payung raksasa 


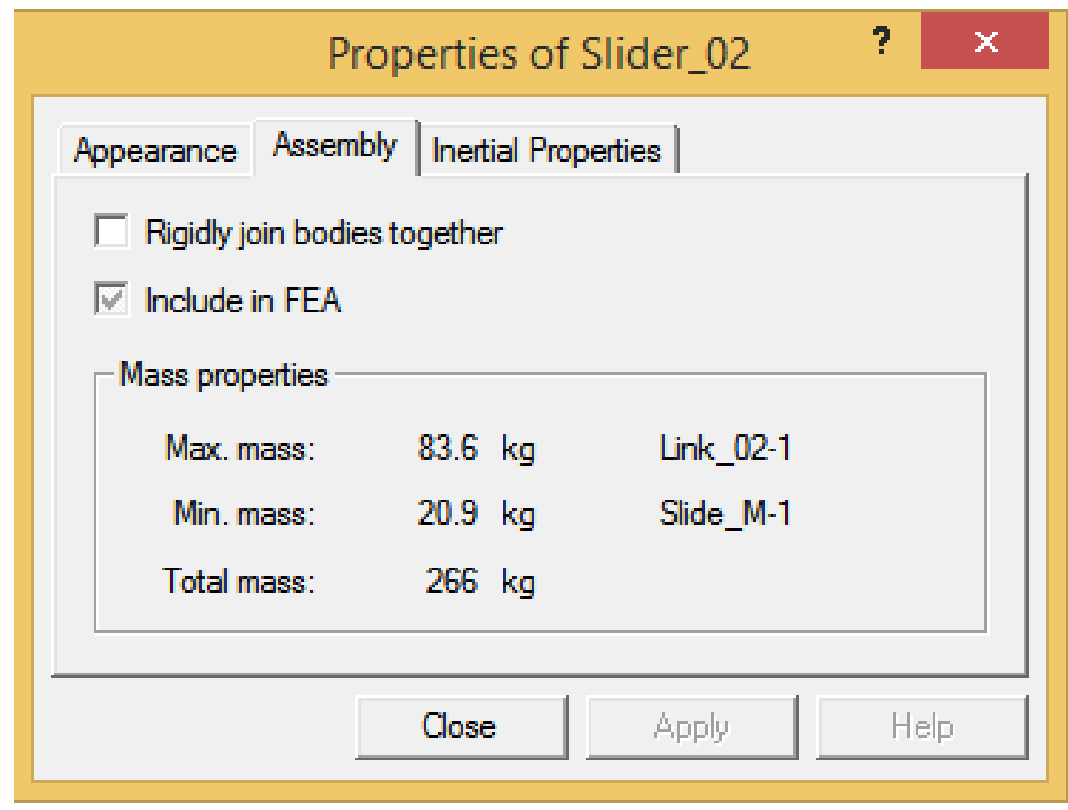

Gambar 4. Properti dari batang utama mekanisme

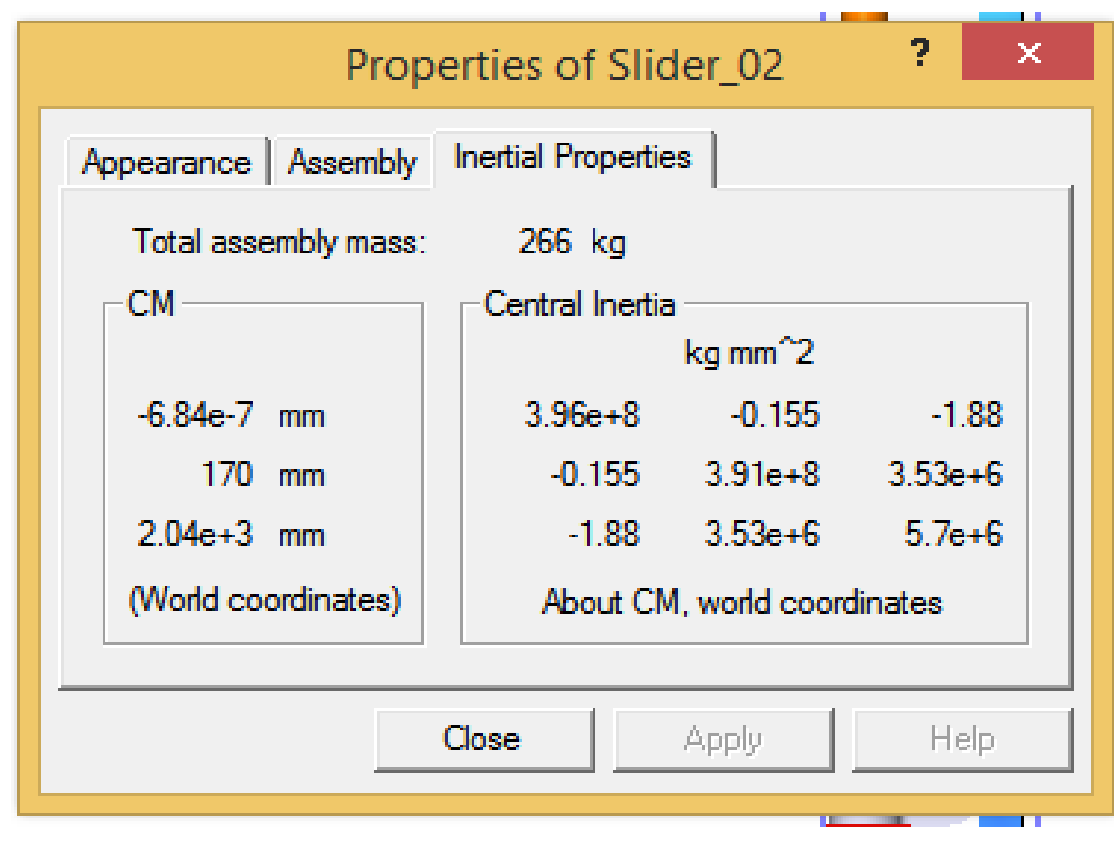

Gambar 5. Properti dari batang utama mekanisme 


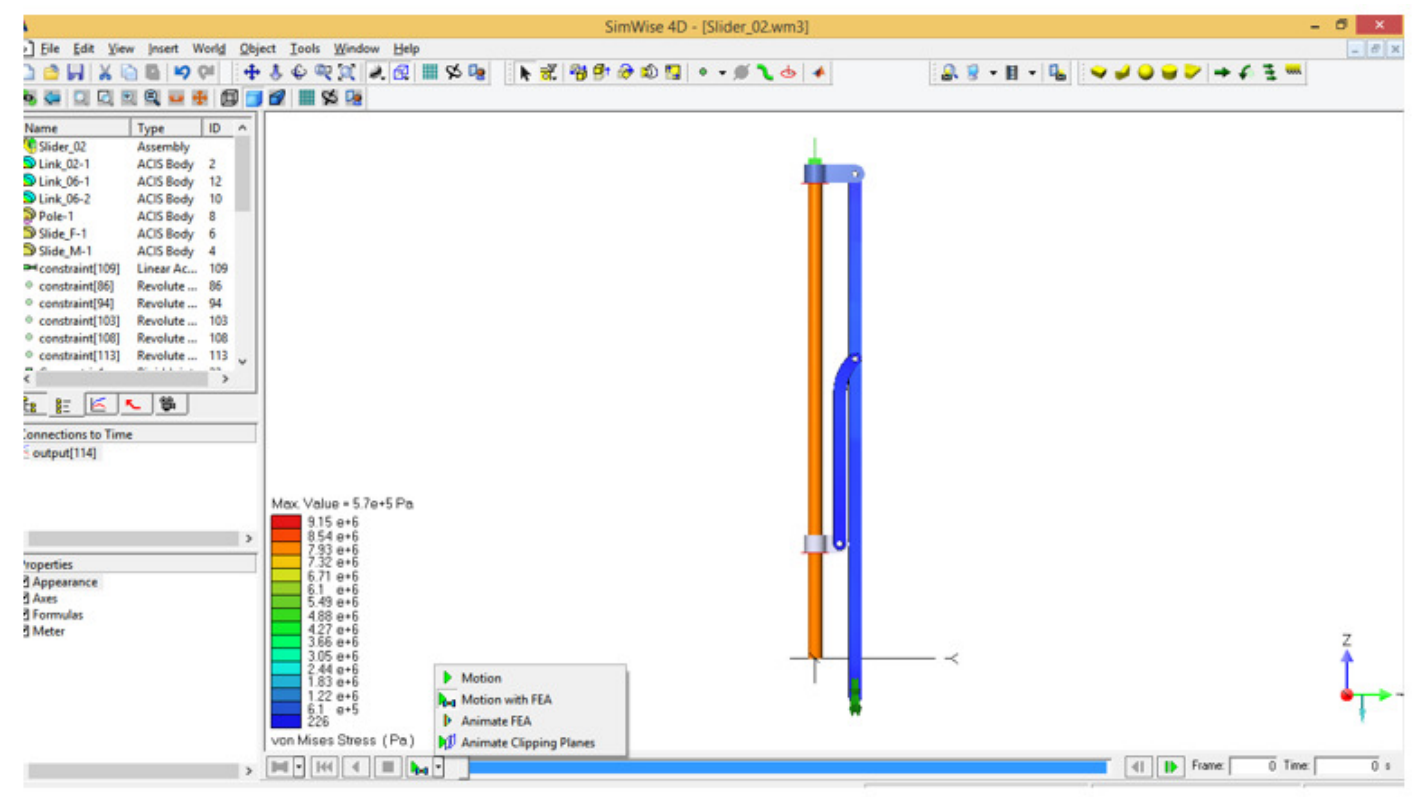

Gambar 6. Perhitungan motion dengan FEA

Tahap awal dibuat diagram benda bebas mekanisme batang utama payung yang akan dianalisis, beban dikenakan diujung bebas batang utama dan slider akan diberi kecepatan sebesar $10 \mathrm{~mm} / \mathrm{s}$ dari posisi diam sampai bukaan maksimum.

Bagian penopang jejari bawah dan atas merupakan bagian yang kritis sehingga harus mendapat perhatian yang lebih selain komponen batang utama mekanisme, bagian ini akan dianalisis kemudian setelah batang utama menghasilkan dimensi yang aman.

Model elemen hingga dibuat dengan dimensi pada Gambar 1, constraint dan beban diberikan seperti pada diagram benda bebas, kemudian digerakkan dengan kecepatan 100 $\mathrm{mm} / \mathrm{s}$ dan dianalisis untuk mendapatkan data tegangan serta perpindahan dari kondisi tertutup sampai terbuka penuh.

Properti dari setiap komponen batang diinitialisasi agar dapat diperhitungkan pada saat eksekusi elemen hingga dilakukan.
Perhitungan pada model dipilih motion with FEA yang menghasilkan kondisi tegangan dan perpindahan pada batang utama pada setiap posisi gerak slider, slider digerakkan dengan kecepatan konstan $100 \mathrm{~mm} / \mathrm{s}$.

Tegangan Von Mises untuk berbagai posisi bukaan ditampilkan pada gambar 7 dan perpindahan untuk berbagai posisi bukaan ditampilkan pada gambar 8 . 


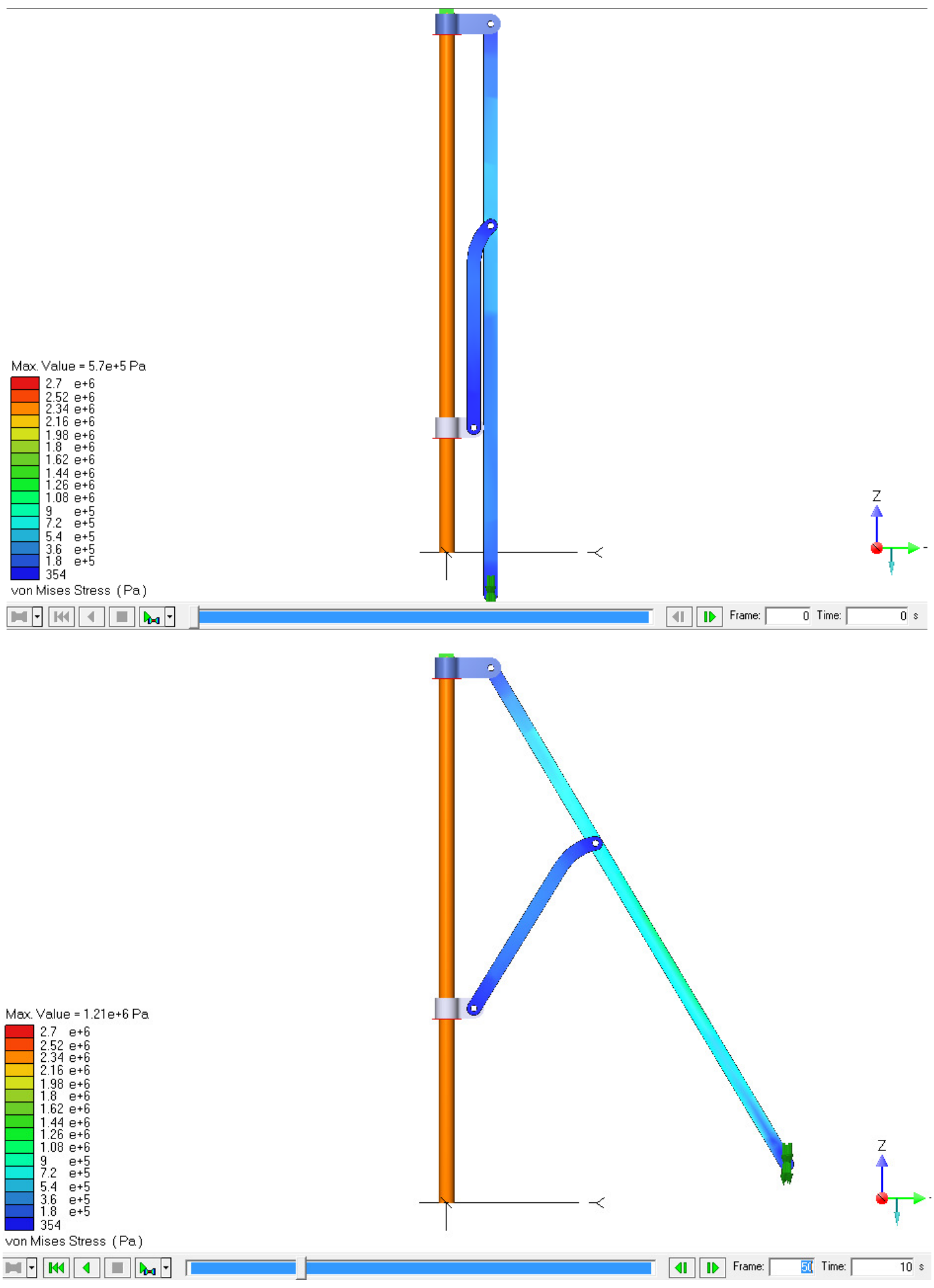

Gambar 7a. Tegangan Von Misses tiap posisi 

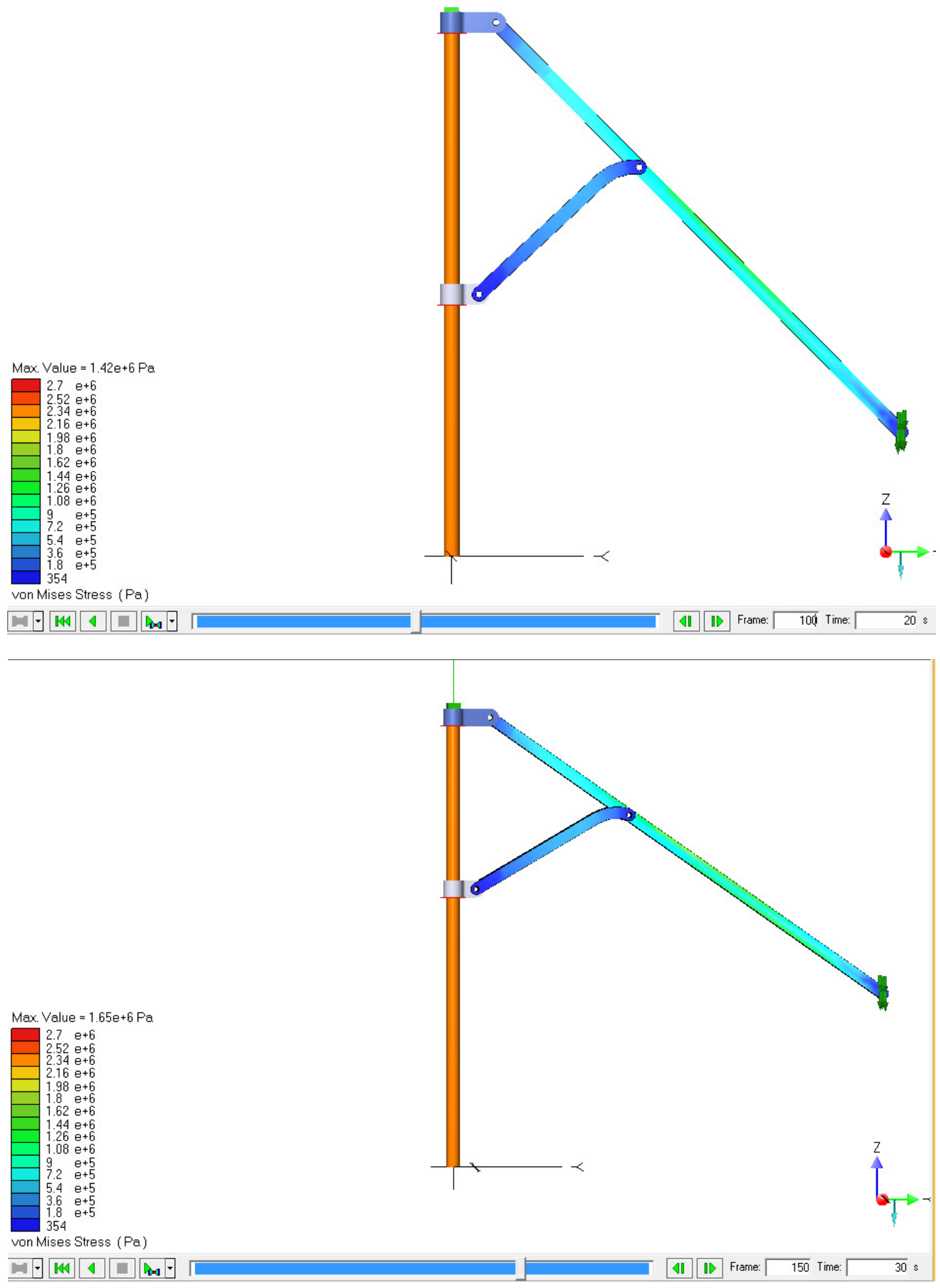

Gambar 7b. Tegangan Von Misses tiap posisi 


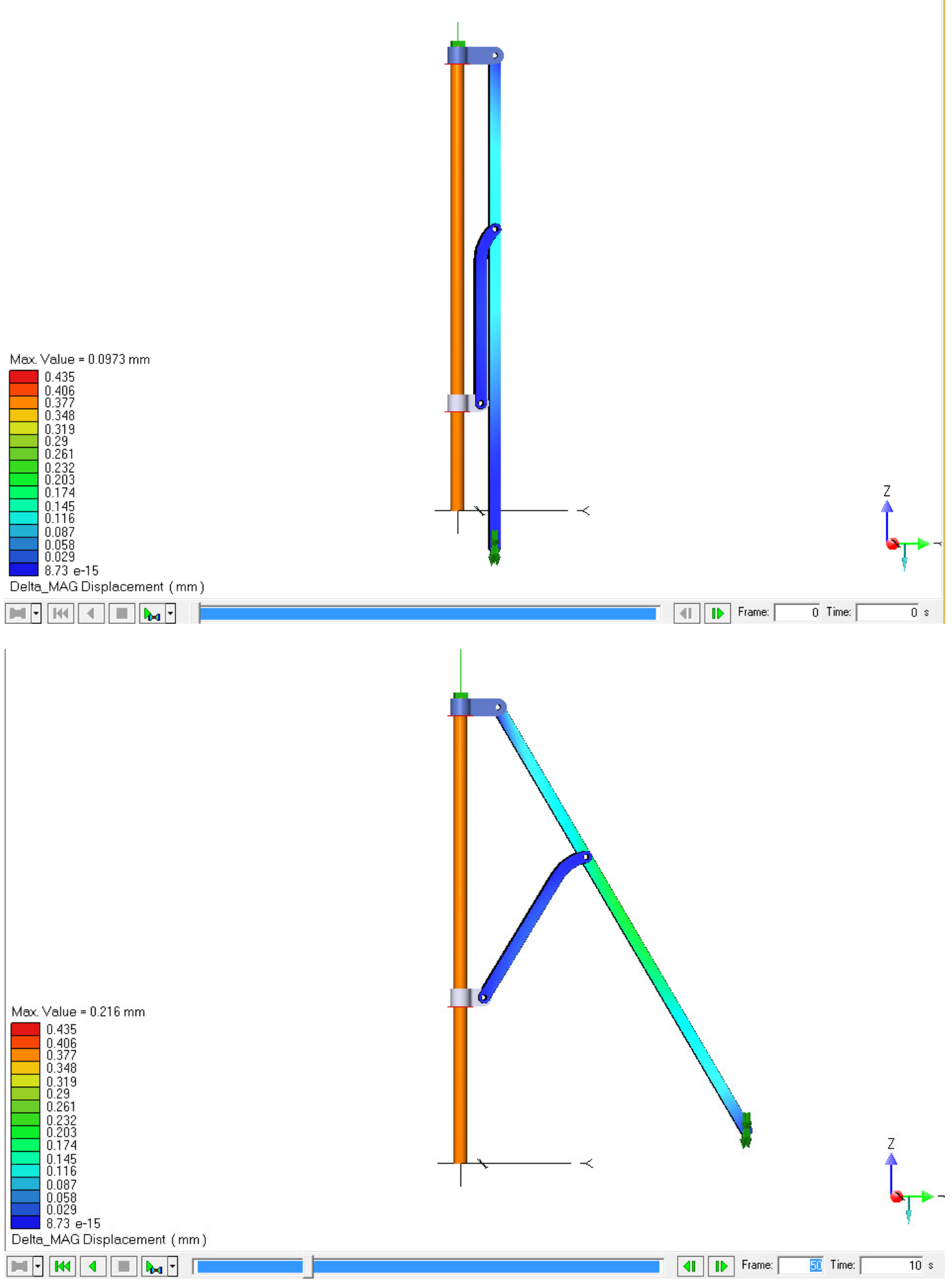

Gambar 8a. Perpindahan tiap posisi 


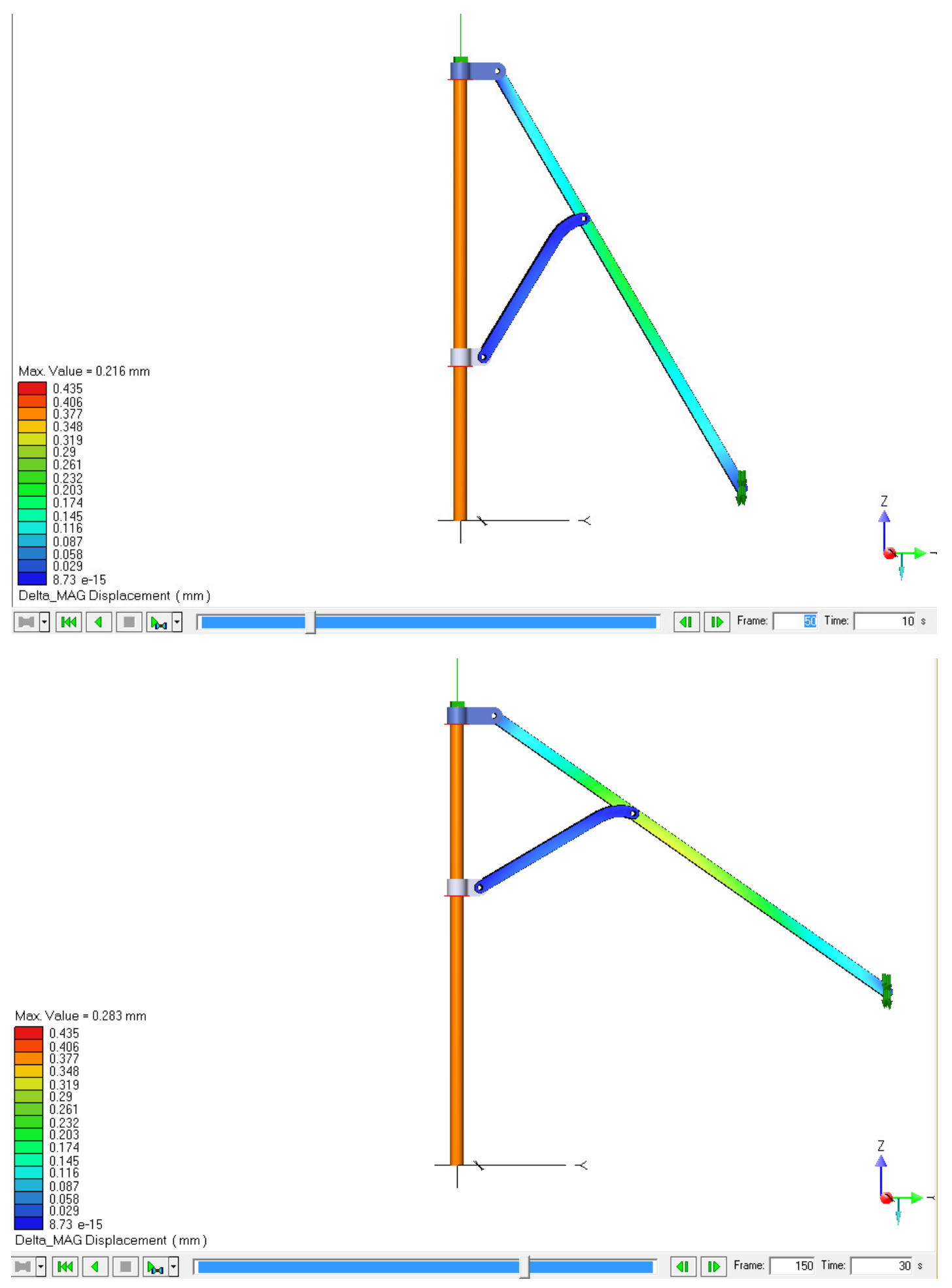

Gambar 8b. Perpindahan tiap posisi 


\section{HASIL DAN PEMBAHASAN}

Data tegangan von misses, regangan dan perpindahan yang terkumpul dari keluaran SimWise 4D diolah dan dibuat kurva hubungannya terhadap posisi seperti pada gambar dibawah ini.

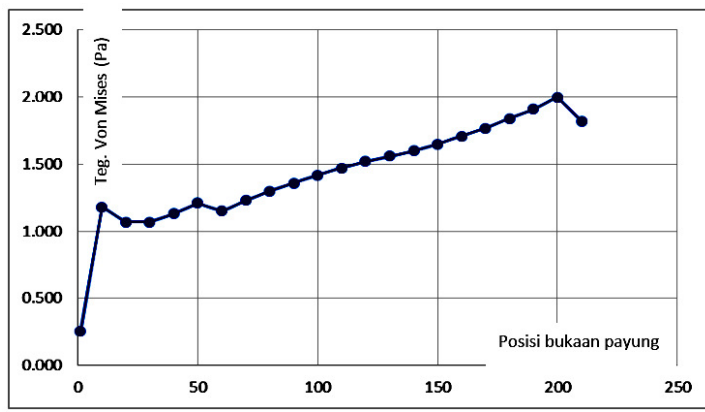

Gambar 9. Kurva hubungan posisi vs tegangan von mises

Dari kurva gambar 9 terlihat tegangan von mises naik sampai posisi ke 200 lalu turun pada saat mencapai posisi payung terbuka maksimum, tegangan maksimum von mises yang terjadi sebesar 2 Mpa.

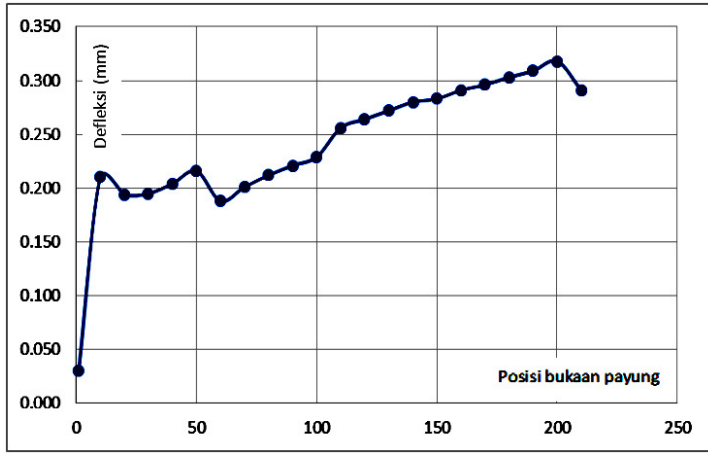

Gambar 10. Kurva hubungan posisi vs perpindahan

Dari kurva gambar 10 terlihat perpindahan naik sampai posisi ke 200 lalu turun pada saat mencapai posisi payung terbuka maksimum, displacement terbesar sebesar 0.3 $\mathrm{mm}$.

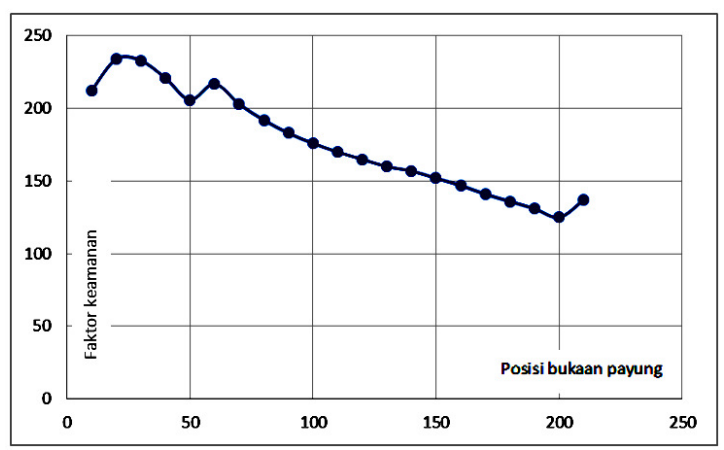

Gambar 11. Kurva hubungan posisi vs faktor keamanan

Kurva pada gambar 11 memperlihatkan FoS dan faktor keamanan yang terkecil terjadi pada posisi 200 yaitu sebesar 125. Masih sangat aman untuk sebuah mekanisme yang bergerak dinamis.

\section{KESIMPULAN}

Dari hasil perhitungan secara numerik memakai perangkat lunak SimWise 4D dapat disimpulkan :

1. Tegangan yang terjadi pada batang utama mekanisme payung raksasa masih dibawah kekuatan luluh material yang dipakai.

2. Perpindahan (displacement) yang terjadi masih memenuhi batasan yang diijinkan

3. Faktor keamanan masih dalam kisaran yang diijinkan TA.

\section{UCAPAN TERIMAKASIH}

Penulis pada kesempatan ini mengucapkan terimakasih kepada Kemenristekdikti atas bantuan dana penelitian melalui program penelitian Hibah Bersaing tahun 2016 dan kepada Jurusan Teknik Mesin FTUnpas atas fasilitas yang dipergunakan dalam penelitian ini.

\section{DAFTAR PUSTAKA}

Santoso G., 2016, Conceptual design mekanisme payung penutup lahan parkir kendaraan, Prosiding Seminar Nasional Vehicle Design \& Engineering, Bandung, Indonesia.

SL Rasch Engineering, 2013, Design and Analysis of Lightweight Structures.

Sandor, 2005, Advanced Mechanism Design: Analysis and Synthesis, 2, Prentice Hall. 